Article

\title{
Land Use in Flood-Prone Areas and Its Significance for Flood Risk Management-A Case Study of Alpine Regions in Austria
}

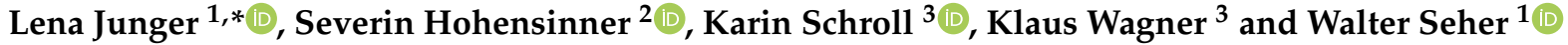 \\ 1 Institute of Spatial Planning, Environmental Planning and Land Rearrangement, Department of Landscape, \\ Spatial and Infrastructure Sciences, University of Natural Resources and Life Sciences, 1190 Vienna, Austria; \\ walter.seher@boku.ac.at \\ 2 Institute of Hydrobiology and Aquatic Ecosystem Management, Department of Water, Atmosphere and \\ Environment, University of Natural Resources and Life Sciences, 1180 Vienna, Austria; \\ severin.hohensinner@boku.ac.at \\ 3 Federal Institute of Agricultural Economics, Rural and Mountain Research, 1030 Vienna, Austria; \\ karin.schroll@bab.gv.at (K.S.); klaus.wagner@bab.gv.at (K.W.) \\ * Correspondence: lena.junger@boku.ac.at; Tel.: +43-1-47654-85513
}

check for

updates

Citation: Junger, L.; Hohensinner, S.; Schroll, K.; Wagner, K.; Seher, W.

Land Use in Flood-Prone Areas and Its Significance for Flood Risk Management-A Case Study of Alpine Regions in Austria. Land 2022, 11, 392. https://doi.org/10.3390/ land11030392

Academic Editors: Matej Vojtek, Andrea Petroselli and

Raffaele Pelorosso

Received: 17 February 2022

Accepted: 4 March 2022

Published: 7 March 2022

Publisher's Note: MDPI stays neutral with regard to jurisdictional claims in published maps and institutional affiliations.

Copyright: (C) 2022 by the authors. Licensee MDPI, Basel, Switzerland. This article is an open access article distributed under the terms and conditions of the Creative Commons Attribution (CC BY) license (https:// creativecommons.org/licenses/by/ $4.0 /)$.

\begin{abstract}
Increasing flood damage has led to a rising importance of land use in flood risk management policies, commonly referred to as the spatial turn in flood risk management. This includes policies aiming at making space for rivers, which, in practice, lead to an increasing demand for land. Although research has been conducted on the variety of policies, the resulting land use conflicts in flood-prone areas have not been paid much attention to. This paper therefore analyses the current land use and its changes in Alpine flood-prone areas in Austria. The results show that space for rivers has been decreasing due to human activities (e.g., river straightening and channel narrowing) since the middle of the 19th century, and settlements have been expanding into flood-prone areas. Furthermore, the share of valuable agricultural land (which is important for food production) located in flood hazard zones is higher in more mountainous areas. Given the limited space for permanent settlement in Alpine regions, these land use changes exert pressure on the availability of land suitable for flood risk management. Therefore, making space for rivers as part of flood risk management policies faces considerable restrictions in Alpine areas.
\end{abstract}

Keywords: flood risk; land use; settlement development; agricultural land use; flood-prone areas; Alpine regions

\section{Introduction}

Flooding is one of the most damaging natural hazards worldwide, with flood risks ever increasing [1]. This can, among other things, be linked to climate change, which is likely to further intensify flooding. Detailed evaluations of climate change impacts on flooding at local level, however, are still inconclusive [2,3]. A second important driver of increasing flood damage is socio-economic development, including an increase in wealth, population development, and settlement expansion in flood-prone areas [4-6].

In order to reduce flood risks, a shift from controlling rivers and hazard prevention to an integrated approach of flood risk management can be observed [7-10]. Integrated flood risk management includes structural and non-structural measures, moving away from a solely engineering task to the inclusion of different disciplines [11,12]. With this paradigm shift, spatial planning has become a crucial part of flood risk management, and related policies are seen as an essential means to prevent flood damage [11]. Scholarly literature uses the term 'spatial turn' to describe the increasing relevance of (mainly undeveloped) land for flood risk management $[13,14]$. According to van Ruiten and Hartmann [14], three aspects can be regarded as valid indicators for this spatial turn in flood risk management: 
"[ ... ] the policy of more space for the river, an integrated approach to the issue, and an approach beyond structural measures". To operationalize the spatial turn, Löschner [13] goes into more detail, including, among other aspects, "policy efforts to widen rivers and improve the connectedness between rivers and floodplains".

Research has been conducted on the implementation of policies addressing 'making space for rivers' [15]. This includes research on the 'Room for River Directive' in the Netherlands [16-18], analysis of the practical implementation of giving space to rivers in Germany [19], and studying the application of the 'Room for River Directive' in Canada [20]. Furthermore, in the UK, there is research on the effectiveness of national planning policy in achieving compromises between space for rivers and space for people. This underlines the "conflict between land and water" [21].

This paper builds upon the aspect of 'making space for rivers', which, in practice, means an increasing demand of land both for river restoration and flood risk management. In consequence, this demand of land for rivers can lead to land use conflicts [21]. Although the implementation of related policies has been widely explored, there is research demand on the quality and extent of land use conflicts in flood-prone areas, particularly in areas with limited space for permanent settlement. This research will address this gap by looking at land cover changes and the current land use in flood-prone areas in Austrian Alpine regions. Considering the aspects of transformation of water bodies, settlement development, and agricultural land, this paper will answer following research questions. How did water bodies and settlements in flood-prone areas change between 1826-1857 and 2016 in Austrian Alpine regions? How are flood-prone areas in Alpine regions currently used (focusing on settlements and agriculture)?

A historic view on the human transformation of Alpine water bodies shows the decreasing space for rivers. As part of flood risk management, structural measures have been applied, including river channelization. Research on the channelization of Alpine rivers shows that, in comparison to other European countries, rivers in Austria have been altered more intensely [22]. These regulations left rivers with limited land availability [23]. Thus, river regulations are the preceding development, making it necessary nowadays to consciously implement policies in order to return space to rivers. However, it is not simply narrowing riverbeds that affect runoff. The use of flood-prone areas for settlements has an additional impact on discharge due to an increase in sealed surfaces water that cannot infiltrate into the ground, impacting the flood event [23]. Besides the relevance of widening rivers as a part of flood risk management, the ecological benefits must not be ignored [24]. The use of floodplains for agriculture as well as settlements often has a negative impact on the aquatic ecosystems $[25,26]$.

Furthermore, a view on settlement development in flood-prone areas will underline the increasing land-take and will show the land use pressure in flood-prone areas. Research has been conducted on the exposure of settlements to flooding on different levels, showing a general increase in built-up land in hazard zones [5,27-29]. Our research will add to this broad spectrum of research on flood exposure by analyzing settlement development in areas up to a one in a 300-year flooding on a cross-regional level.

Besides settlement development, this paper presents an analysis of agricultural land in flood-prone areas, with a focus on land valuable for regional food production. A considerable share of areas in flood-prone areas is used for agricultural purposes [30]. The potential for mutual impacts is accordingly great, which makes it important for inclusion in this research.

The paper aims at showing land use dynamics in flood-prone areas and the resulting consequences for flood risk management, including the limitations of giving space to rivers. 


\section{Materials and Methods}

\subsection{Study Area}

The research presented in this paper focuses on Alpine regions in Austria, and even though they are not homogeneous, they share similar spatial challenges. First of all, Alpine areas are prone to multiple natural hazards, including snow avalanches, landslides, and floods; floods, however, cause the most economic damage [31]. Furthermore, the space for permanent settlement is limited due to topography. According to the Alpine Convention, $65 \%$ of Austrian territory is part of the Alps. However, only $35.7 \%$ of the area for permanent settlement is situated within the Alps. This results in only $21.18 \%$ of the Austrian Alps being suitable for permanent settlement [32]. In addition to the limited space, the on-going conversion of (mainly) farmland to housing, commercial and industrial areas, and traffic and recreation infrastructure increases the pressure on open-space land uses. For Austria, this so-called land-take amounted to approximately 12 hectares per day in 2020 [33]. The increasing land-take in combination with limited space for permanent settlement particularly exerts pressure on existing and available land resources for flood runoff and flood retention [34].

The research is based on GIS analysis of spatial data on the land use of flood-prone areas, including settlements, water bodies, and agricultural land. For water bodies and settlements, historical as well as current data exists for the catchment area of the rivers Rhine (Vorarlberg), Salzach (Salzburg), and Drava (East Tyrol and Carinthia) (see Figure 1). The agricultural land use was analyzed based on current data, which was available for the whole of Austria.

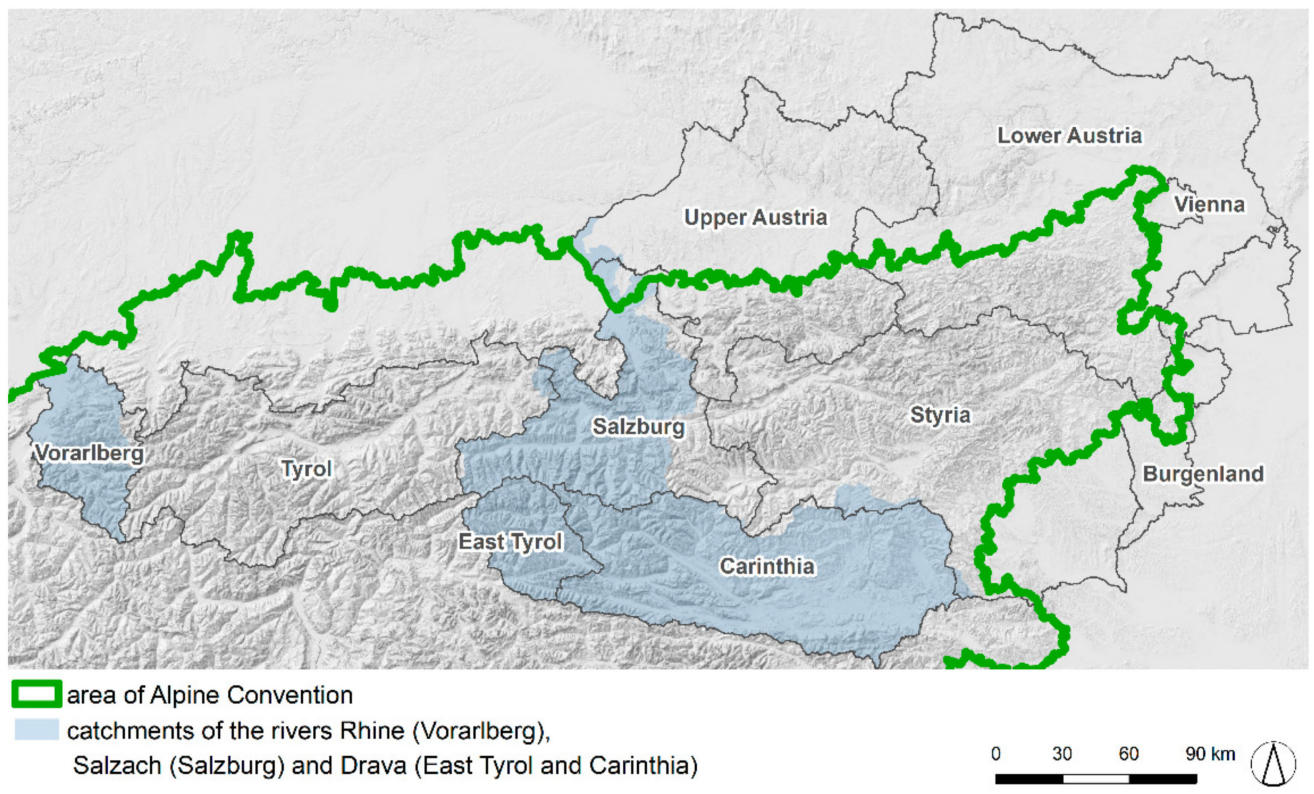

Figure 1. Study area (source of borders: Federal Office of Metrology and Surveying (BEV), Alpine Convention; source of digital terrain model: GELAENDE-basemap.at, accessed on 28 February 2022).

\subsection{Data}

The historical settlement data and the data on water bodies are based on the Franziscean Cadastre (1826-1859), which was digitalized by Hohensinner et al. [35]. The use of historical data can lead to some inaccuracies; the Franciscean cadastre shows variations in accuracy between intensely used valley areas and more remote locations higher up [35]. For the analysis of settlements, the lesser details at high altitudes does not matter as much, because the main settlements were located in the valleys.

For current land use (2016) based on LISA (Land Information System Austria) data, several datasets were combined [36]. To add detailed differentiation within agricultural land uses, the IACS (Integrated Administration and Control System) dataset was used [37]. 
Further, the glaciers are based on Buckel and Otto [38], and a dataset on mid-sized rivers and smaller ponds was gathered from OpenStreetMap [39]. For small rivers and streams, data from a project on "Strategic Planning for Alpine River Ecosystems" were used [40]. The different datasets were combined and prepared by Hohensinner et al. [35]. For the recent agricultural land analysis, the IACS spatial dataset of 2018 was used. For the exposure analysis of particularly valuable agricultural land, the results of the BEAT project were used as a spatial dataset, comprising the areas of valuable agricultural land [41]. For the economic evaluation of agricultural land, regional standard output coefficients were considered [42]. The standard output represents the average monetary value of agricultural output at farm-gate price in euro per hectare or per head of livestock. In order to quantify the decline of agricultural land in recent decades, the data of the agricultural structure survey and IACS data from the Green Report 2021 were used [43].

Flooding area combines information derived from the existing flood hazard maps provided by the Federal Water Engineering Administration (Bundeswasserbauverwaltung) and the Austrian Service for Torrent and Avalanche Control (Wildbach- und Lawinenverbauung), as well as data on 200-year flood events from HORA (Austrian Flood Hazard Map). The flood-prone area used for the exposure analysis encompasses all available flooding data in Austria, showing the area potentially affected by a 300-year flood event, which will be referred to as the flood-prone area in this paper. The focus is put on a 300-year flood, which includes areas with lower probability of flooding, in order to integrate areas that might be affected more by flooding in the future due to climate change impacts. Additionally, by covering an area of a 300-year flood in this research, 'protected' areas behind structural flood protection measures are included in the land use analysis of flood-prone areas. These data were also prepared by Hohensinner et al. [35].

\subsection{Methods}

\subsubsection{Human Transformation of Alpine Water Bodies}

In order to ascertain human modifications of the Alpine channel network, the historical and current active channels, i.e., water-covered areas and adjacent unvegetated sediment bars, were vectorized using ESRI ArcGIS 10.6. A comparative analysis yielded quantitative losses of running waters as a consequence of river channelization and flood prevention measures. The areal changes in standing water bodies (lakes, ponds, reservoirs) were derived analogously [35].

\subsubsection{Settlement Development}

The settlement area for this research includes buildings and adjacent streets, squares, gardens, and smaller parks. The method applied to research the development of settlements inside flood-prone areas is described as a "classical approach for flood exposure assessment" by Papilloud et al. [44], which has been broadly applied. Using ESRI ArcGIS 10.6., the settlement development was calculated by overlapping the historical with the current data; the difference between the datasets represents the development. To calculate the exposure of settlements to flooding, the results of the first step (settlement development) were further crossed with the flood-prone area. This made it possible to see the difference between the development inside and outside flooding areas. Besides the temporal aspect of the analysis, it was also interesting to look at the regional differences. For this purpose, the data were intersected with the municipality borders, showing settlement development inside and outside flood-prone areas per municipality. The results from the GIS analysis were further processed in Excel to calculate the relative development, which is based on the factor calculated by dividing the current settlement area by the historical area.

The historical data in East Tyrol and the eastern part of the province Carinthia was less detailed than in the other regions, and settlements included grassland to some extent [35]. In order to correct the settlement extents, as an estimate, half of the historical settlement area was excluded from the investigation based on a previous analysis of local sample data. The results of some individual municipalities may therefore be less accurate. Even though 
the analysis was broken down to a municipality level, the spatial distribution was observed on a regional level. In addition, due to some spatial inaccuracy between the historical and the current data [35], the analysis worked with the assumption that settlement areas have not been decreasing in a significant manner since the mid-19 ${ }^{\text {th }}$ century. Therefore, settlement areas that appear in the historical context but do not in the current data were added to the current settlement.

The flood-prone area is based on current calculations but was also used for the historical analysis. It is likely that a 300-year flood in the historical context covered more ground. The results therefore only show the minimum of settlements exposed to a 300-year flood.

\subsubsection{Agricultural Land}

In the case of agricultural land, the analysis is based on the IACS dataset of 2018. It allows a detailed differentiation of agricultural land use on field level (18 land use categories). Spatially overlapping the land use data with the flood-prone areas shows the agricultural areas affected by flooding. To calculate the economic value of crop production in flood-prone areas, the spatial land use areas in hectares were multiplied by the regional standard output coefficients (according to crop type). This reveals the economic value of crop production within flood-prone areas (livestock production was not taken into account). It allows regionally differentiated conclusions on how strong the pressure might be for farm enterprises and where the situation might be more conflict-ridden between farming and flood risk management. Results of the research project BEAT categorized agricultural land within agricultural production zones based on their relevance for regional food supply [41] Intersecting flood-prone areas with these data shows potential pressure in the view of food security. The analysis was carried out for Austria and specifically for the Federal State of Carinthia as an Alpine region.

\section{Results}

\subsection{Human Transformation of Alpine Water Bodies}

Since the first half of the 19th century, almost all larger running waters in the Austrian Alps have been severely modified by humans due to river straightening and channel narrowing. The main objective for the comprehensive hydraulic works was on land reclamation, improvement of navigation, and log driving. As a consequence, since 1826-1859, $40 \%$ of the former surface area of the Alpine running waters have vanished (see Figure 2). Expressed in a simplified manner: on average, rivers and streams have lost $40 \%$ of their former active channel width (omitting reductions in channel length due to river straightening). The data clearly show truncated flood retention and conveyance capacities due to the infilling of former channel areas. Surprisingly, stagnant water bodies have slightly increased in surface area. The reason for this can be found in new glacier lakes that have emerged after glacier decline and-most of all-in the construction of large reservoirs for hydro-energy purposes. Due to their storage capacity, the latter can partly help mitigate flood risks in Alpine environments [45]. Figure 2 also reveals the comprehensive areal reduction in ice-covered areas as a consequence of glacier retreat. Glaciers formerly covered $2.6 \%$ of the study area; today, they merely form $0.7 \%$. This equals to an areal reduction of $73 \%$. Because glaciers annually and inter-annually buffer precipitation in form of ice, they significantly influence the flow and flood regime of Alpine rivers. The severely reduced glaciated areas indicate significant losses in runoff storage capacity, resulting in increasing surface runoff during precipitation events [46]. Thus, it amplifies the flood risk in downstream valley sections.

\subsection{Land Use in Flood-Prone Areas}

\subsubsection{Settlement Development}

Although the area for running waters and glaciers has been reduced within the time frame of the analysis, settlement areas have expanded. These analyses were conducted for 
the catchments of the rivers Rhine, Salzach, and Drava, which include main parts of the Austrian federal states of Vorarlberg, East Tyrol, Salzburg, and Carinthia.

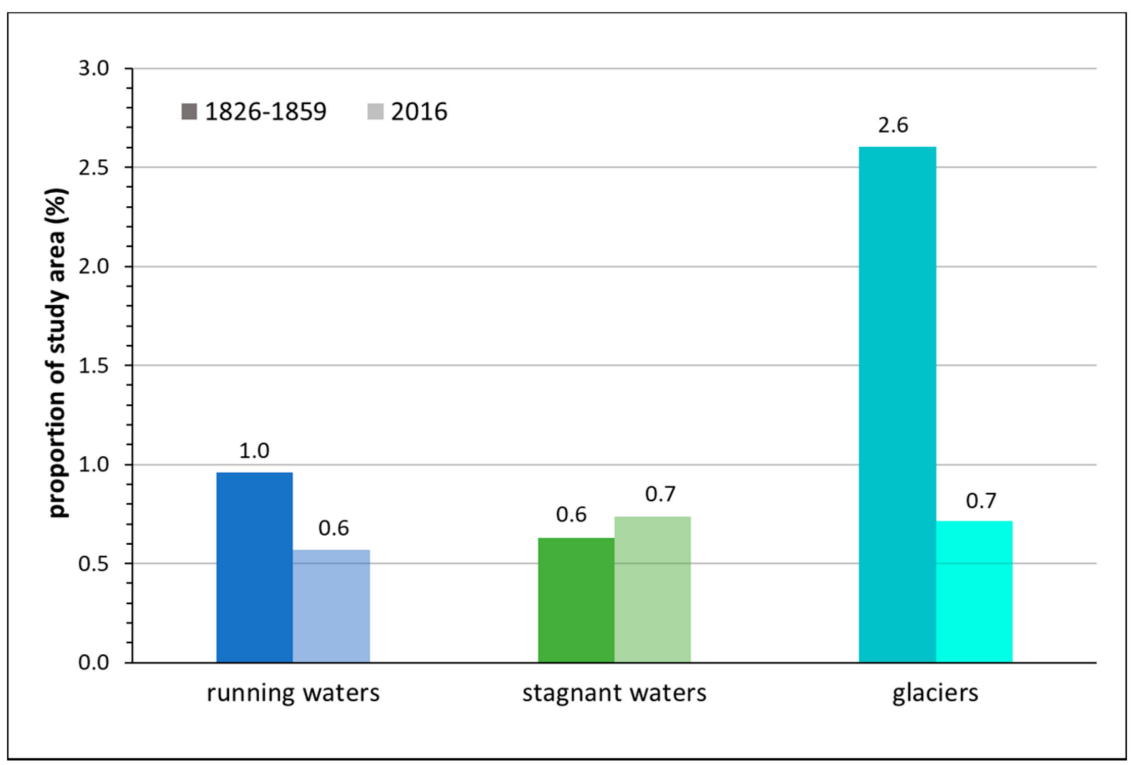

Figure 2. Proportions of the Alpine water bodies and glaciers in the Austrian catchments of the rivers Rhine, Salzach, and Drava (\%) (left column: 1826-1859, right: 2016).

First, data on the general settlement development (i.e., inside and outside flooding areas) between 1826-1859 and 2016 were analyzed. The results show that development was primarily taking place in areas around the main cities and in larger valleys, such as the Rhine-Valley in Vorarlberg. Settlement expansion did not occur to the same extent in the mountainous regions. A comparison of the amount of settlement area per region historically and currently was made (see Figure 3). Although in the historical context, the percentage of settlement area per region is below $0.5 \%$, in 2016, it increased to $3.6 \%$ in Vorarlberg and to approximately $2 \%$ in Carinthia and Salzburg. The settlement development therefore varies between the different Alpine regions but has significantly increased throughout the whole study area.

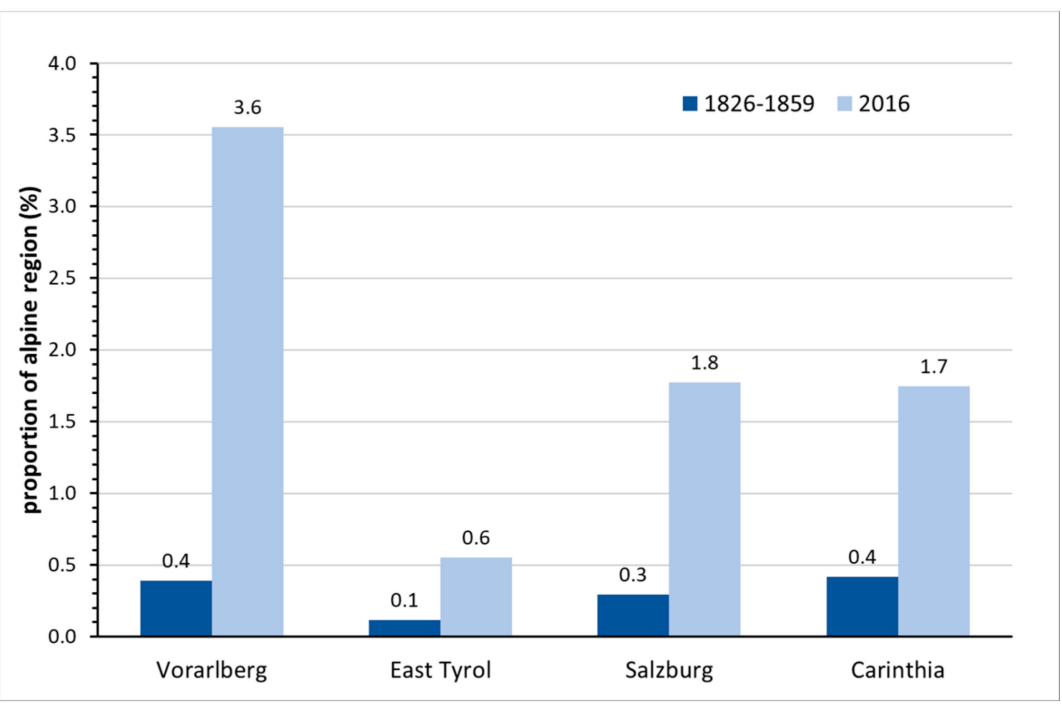

Figure 3. Proportion of settlement area per region.

Besides the general settlement development, the amount of space that is affected by flooding is an important variable. The results show that in Vorarlberg, $10 \%$ of the study 
area is potentially affected by flooding. In Carinthia, it is 7\%, in Salzburg 5\%, and in East Tyrol, $3 \%$. At local level, considerable differences within each federal state can be found, from flood zones covering $97.6 \%$ of the surface area of the municipality of Altach to $0.89 \%$ in Dünserberg (both located in Vorarlberg). These differences derive from the municipality's location being either in a broad valley or in a very mountainous area. Thus, municipalities were and are affected by flooding in a very different way.

To show the settlement areas exposed to flooding, development inside and outside flood-prone areas was analyzed, as well as the absolute and relative values, which are based on the factor calculated by dividing the current settlement area by the historical area. The results from the historical analysis show that, for the whole study area, $21 \%$ of settlement areas were located within flood-prone areas. In 2016, this amounted to $29 \%$; therefore, an increase in development in flood-prone areas can be detected. Differences can be observed when comparing absolute and relative development. The absolute value indicates a higher increase in settlements outside of flooding areas, whereas the relative value is higher for development inside flood-prone areas. On the one hand, this is caused by the limited use of floodplains for development in the 19th century, when adding just a few buildings could result in a high relative value. On the other hand, a shift towards using (former) floodplains for development can be observed.

Besides the temporal aspect of the analysis, the regional differences-based on the municipalities -was explored. According to the absolute numbers, settlement development in flood-prone areas shows a similar dissemination as the general settlement development. Municipalities with a high settlement expansion in flood zones are located in urban areas and the main valleys. Peripheral regions show less development in flood-exposed areas. This demonstrates the link between settlement development in flood-prone areas and the general settlement dynamic within a municipality. Furthermore, a correlation can be found between the number of buildings and infrastructure located in flooding areas and the amount of land potentially affected by flooding within a municipality.

To gain further insight into the spatial distribution of flood damage potential, the amount of settlement area situated in flood-prone areas per municipality was calculated.

Especially in Salzburg and Carinthia, it can be observed that, in more mountainous and peripheral regions, a higher share of settlements is located in flood-prone areas (both in the historical and the current context; see Figure 4).

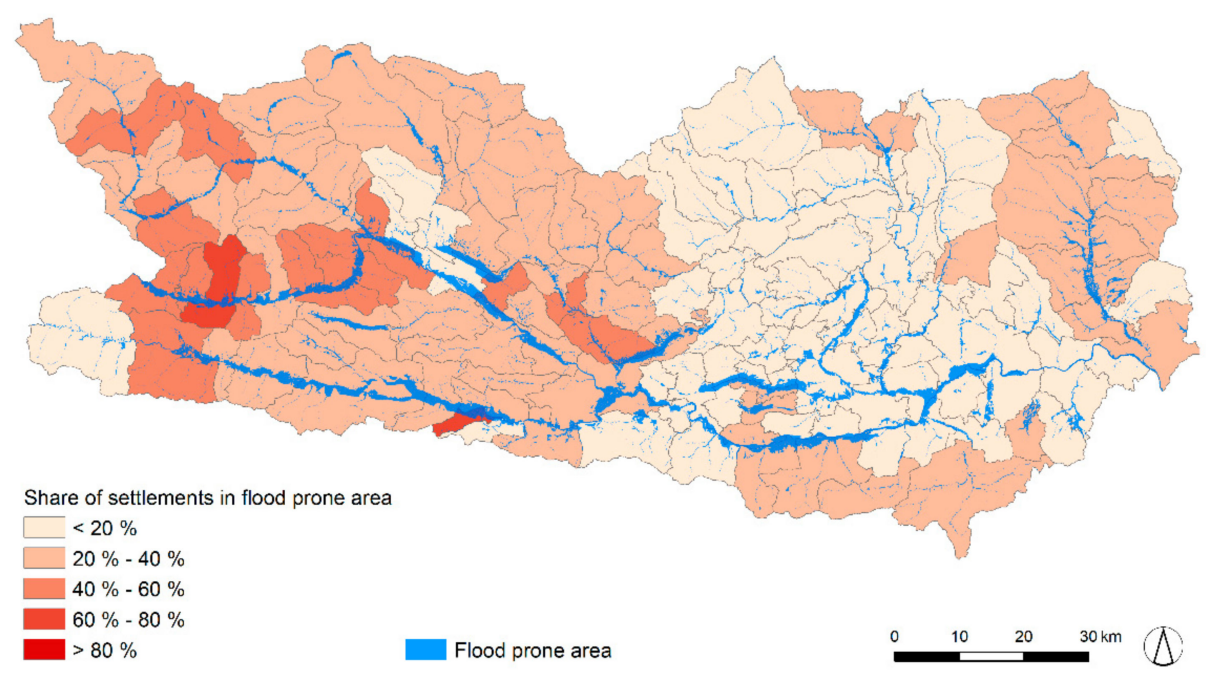

Figure 4. Percentage of settlement area potentially affected by flooding in Carinthia, 2016 (source of borders: Federal Office of Metrology and Surveying (BEV)). 
By the results of this exposure analysis, the growing pressure on flood-prone areas and the increase in flood damage potential due to settlement development becomes evident.

\subsubsection{Agricultural Land}

As settlements are expanding, agricultural land is declining. In the period from 1951 to 2020, the agricultural area in Austria has decreased by 35\% (excl. alpine pastures) [43]. Within the last 20 years, agricultural areas have decreased by $14 \%$, from about 3 million ha (year 2000) to 2.6 million ha in 2020 [43]. Figure 5 shows the decline in agricultural land area over the last 20 years, differentiated by Austrian federal states. The significantly higher decline in the Alpine parts of the country is clearly visible. In Carinthia, the southernmost province, the decline in agricultural area was $21 \%$.

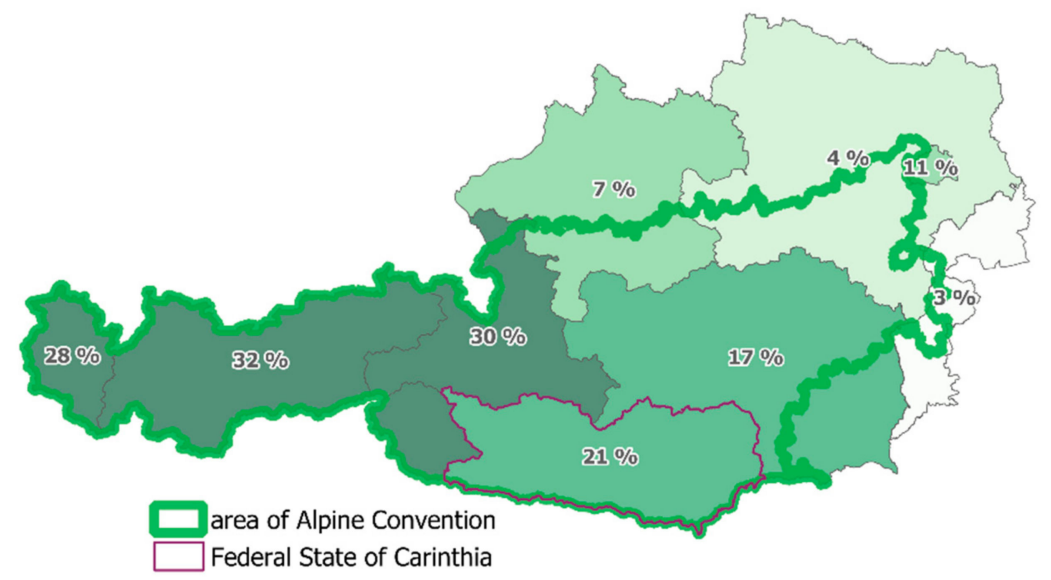

Figure 5. Decline in agricultural land in Austrian federal states between 2000 and 2020 in \% (source of borders: Federal Office of Metrology and Surveying (BEV), Alpine Convention).

In total, 38\% of Austria was used for agriculture in 2018, which amounts to 3.2 million ha (including 0.6 million ha of alpine pastures). At municipality level, this share of agricultural area varies greatly, for example, in municipalities in Carinthia, it differs between 1\% and 56\%. According to the spatial intersection of agriculture with flood-prone areas, $7.7 \%(246,300 \mathrm{ha})$ of Austrian agricultural areas are situated within flooding areas. In Carinthia, this share is $8.2 \%$. The spatial distribution of these areas is, of course, not uniform, and the share of agricultural land within flood-prone areas varies greatly by municipality. In Carinthia, for example, in the municipality Villach, it is $62 \%$, in four others, it is approximately $50 \%$, and in 12 municipalities, it is still more than $20 \%$ (see Figure A1 in Appendix A).

Looking at agricultural land use in flood-prone areas of Carinthia in detail fodder growing $(27.5 \%)$, extensive grassland $(24.2 \%)$, feed grain $(20.9 \%)$, and intensive grassland $(17.4 \%)$ are the most predominant of 18 land use categories. Within the entire region of Austria, intensive grassland (23.2\%), feed grain $(21.5 \%)$, extensive grassland $(15.2 \%)$, fodder growing $(10.4 \%)$, and oleaginous fruit $(8.3 \%)$ are the predominant land use categories. In the Alpine region, there is proportionally more field fodder and extensive grassland, whereas bread crop, oleaginous fruit, and intensive grassland are less present (see Figure A2 in Appendix A).

While the first part was looking at agricultural land in general, in the next step a focus is put on land valuable for food production and the economic value of agriculture. About $42 \%$ of Austrian agricultural areas are considered particularly valuable for agricultural use-due to their relevance for regional food supply_-by the research project BEAT [41]. In order to define valuable agricultural land, the natural characteristics for agricultural production, the resulting production potential - also under climate change conditions-and the regional distribution at the level of small-scale agricultural production areas were considered.

Intersecting these valuable agricultural areas with flood-prone areas reveals that in Austria, $12 \%(157,200$ ha in total) of the total agricultural production areas designated as valuable are located in flood risk areas, whereby their spatial distribution varies greatly. 
Figure 6 shows the small-scale agricultural production areas (areas of similar agricultural production conditions) and the associated share of the total valuable area in the respective production area that lies within flood-prone areas.

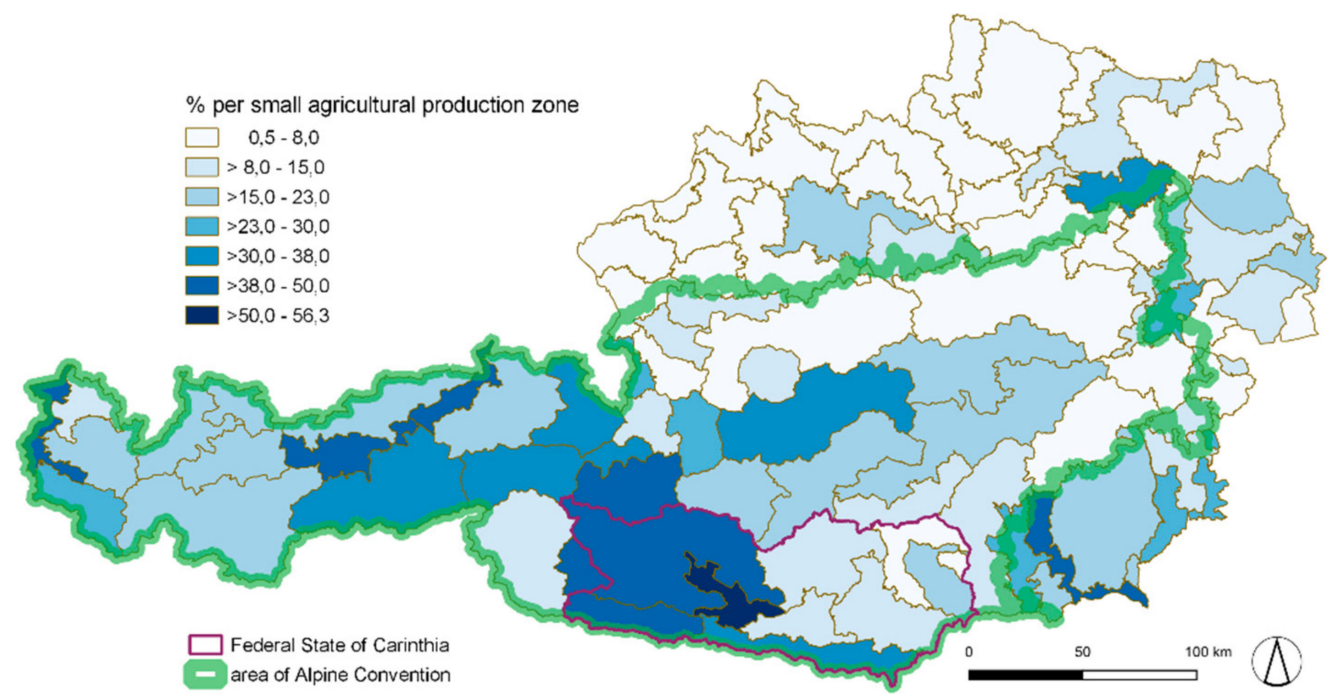

Figure 6. Share of high value agricultural area in Austria situated in flood risk zones per small agricultural production zone (=grey polygons), 2018 (source of borders: Federal Office of Metrology and Surveying (BEV), Alpine Convention).

Particularly in Alpine regions, a greater proportion of soils identified as important for food security tend to be located in flood-prone areas. Whereas the Austrian average of high value agricultural land situated within flood-prone areas is $12 \%$, Carinthia has a share of $21 \%$. Figure 7 shows the distribution of this share for Carinthian municipalities.

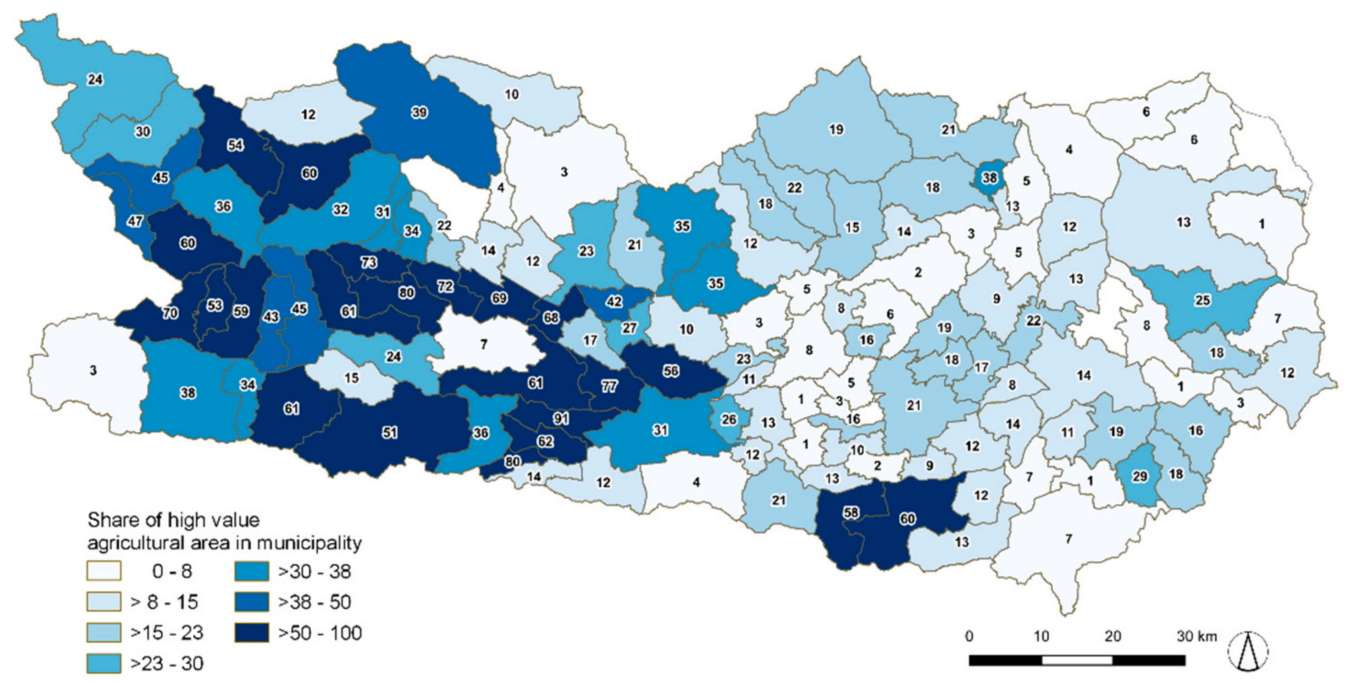

Figure 7. High value agricultural area in Carinthia situated in flood risk zones, share of high value area per municipality, 2018 (source of borders: Federal Office of Metrology and Surveying (BEV)).

The economic value of agricultural areas is calculated by multiplying the hectare of agricultural land in flood-prone areas with an average regional Standard Output (SO). Figure 8 shows the production value of agricultural land in flood-prone areas per municipality. Very high in absolute figures is the agricultural production in flood-prone zones, for example, in the municipalities in St. Andrä, Klagenfurt, Wolfsberg, Hermagor-Pressegger See, and Spittal/Drau. In addition to the absolute numbers, the relative share of agricultural production value at risk is equality important for farm enterprises and food production. 
For example, in the communities Freistritz an der Gail, Weißenstein, Baldramsdorf, Nötsch im Gailtal, and Spittal/Drau, the relative share is above 60\%. The relative value takes the different municipality sizes into account and shows especially high numbers in the south west of Carinthia.

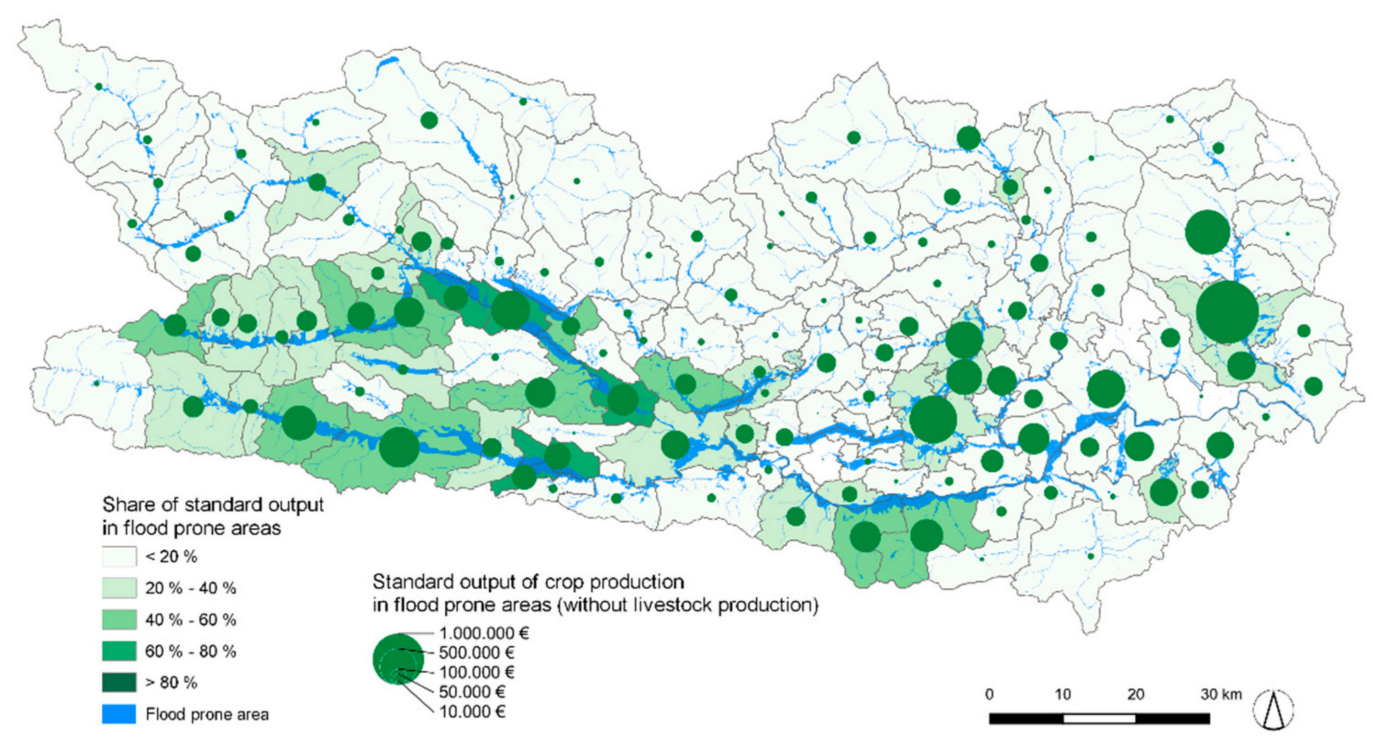

Figure 8. Standard output in EUR of agricultural areas (only value of crop production in intersecting areas-without livestock value) situated in flood-prone areas-sum per municipality and share within flood-prone areas, 2020 (source of borders: Federal Office of Metrology and Surveying (BEV)).

In this calculation, only the standard output values of crop production are considered. In order to be able to assess the full economic exposure, it would also be necessary to include animal production, which is, in part, closely intertwined with crop production.

\section{Discussion}

This research investigated land use in flood-prone areas to assess the pressure these areas are undergoing and the resulting consequences.

In the case study area, the space for river channels has been reduced by $40 \%$ since the middle of the 19th century. In addition, research shows a strong reduction in wetlands there [35]. This significant reduction was caused by river straightening and drainage works in order to decrease the impacts of frequent flood events and to reclaim wetlands for development and intensified agriculture. In the long run, however, these measures led to an increase in flood hazard due to the decreasing space for runoff in the case of floods with low and medium probability [23]. Furthermore, the reduction in glaciers impacts flood runoff. These past developments underline the importance of policies for making space for rivers, not only to reduce flood risks but also to improve the ecological situation of riverine landscapes.

In the case study area, settlement development between the middle of the 19th century and 2016 took place inside and outside flood-prone areas; however, the relative growth is significantly higher inside flooding zones. This result shows a shift towards the use of flood-prone areas for settlement development, which depicts an increase in flood damage potential. This rise in damage potential can also be observed in other exposure-related studies [5,27-29,47]. A multi-hazard exposure analysis for Austria shows a general increase in buildings by 643\% between 1919 and 2012, properties exposed to river flooding have grown by $650 \%$, and buildings exposed to torrential flooding have risen by 594\% [29]. A general increase in flood damage potential due to settlement development can therefore be observed throughout the scientific literature.

Besides settlement development, our research results also point out that the share of settlements affected by flooding is higher in mountainous regions. In Alpine regions, the space for permanent settlement is limited and, due to the topography, is mainly located in the 
valleys. At the same time, flooding zones cover big parts of the valley floor. Therefore, there is an overlapping of flood-prone areas and the area for permanent settlement. Land use pressure on flood-prone areas is not limited to Alpine regions in Austria; other mountain areas face similar challenges of settlement expansion and decreasing space for flood runoff [48].

When it comes to the demand of making space for rivers, agricultural areas are the first choice. They provide areas for infiltration and runoff, with potential flood damages being on a lower level compared to settlement areas. The results show that agricultural land is decreasing, with Alpine regions showing a greater decline. In addition, the percentage of agricultural land within flood-prone areas is higher in mountain areas than outside. To gain a better understanding of the impact of flooding on agricultural land, a differentiation between agricultural areas with different characteristics is necessary. According to Grüneis et al. [30], the flooding of agricultural land results in quantifiable economic losses for farmers such as crop damages, erosion, landfall silting, and contamination, as well as hardly quantifiable environmental damages. These economic losses depend on crop species, growth stage, and soil properties and affect not only single-farm enterprises but the whole agricultural sector. This leads to macroeconomic questions of saving regional food supply, which has recently gained more importance, especially due to the increasing land-take by settlements and thus decreasing agricultural land. The results show that, at a national scale, the percentage of highly valuable agricultural land in flood-prone areas is higher in Alpine regions. This is also underlined by regional results. The western part of Carinthia is more mountainous (which is reflected in the limited space for permanent settlement-see Figure A3 in Appendix A) and also displays a higher amount of valuable farmland in flood-prone areas than the eastern part.

In the example of Carinthia, our results show that the share of settlements and valuable agricultural land in flood-prone areas is higher in pronounced mountain regions. The overlapping of flood-prone areas, valuable agricultural land, and settlements is likely to reduce the options of providing land for flood risk management and river restoration.

Research on the current use of former floodplains in Austria in 2003 concludes that over half of them are nowadays used for field crops and grassland [49]. The use of former floodplains for agriculture contributes to the fact that valuable agricultural land is nowadays located in flood-prone areas. The higher amount of valuable agricultural land in flood-prone areas in Alpine regions is further explained by a higher soil quality in the valley areas and the topography, which limits the use of space for agricultural production.

Research by Haidvogl et al. [50] in the area of St. Pölten in Lower Austria discusses the interdependencies of flood protection measures and settlement development. In combination with population growth, the demand for building land, and the construction of flood protection measures, settlement development along the river Traisen in 'flood-protected' areas was encouraged [50]. However, there remains a residual flood risk after the construction of flood protection measures [51]. The so-called 'levee-effect' or 'safe-development paradox' describes an increasing flood damage potential in areas with residual risk [52,53]. This research did not specifically focus on areas with residual risk behind levees due to the scale of the analysis. However, these areas are included because of the extent of the flooding areas applied. The increasing settlement development in flood-prone areas can therefore be connected to the construction of flood protection measures and the creation of 'flood-protected' areas. Besides the 'levee-effect', the limited space for permanent settlement in Alpine areas and the general increase in settlements led to an increase in flood damage potential.

Based on the results, consequences for flood risk management can be derived. Making space for rivers to reduce future flood damage is an important approach that is confronted with limited space and land use pressure in Alpine regions. Many former floodplains, which nowadays could be used for river restoration, e.g., local widening of watercourses or reconnecting rivers with previous river branches, were often claimed by settlement and agriculture. In other countries, the approach of making space for rivers also faces difficulties $[19,20,24]$. In general, research suggests that a broad inclusion of relevant stakeholders 
at different governmental levels is necessary to implement a flood risk management that aims to make more room for rivers $[16,19]$. One of these disciplines is spatial planning, which takes on an important role when it comes to keeping flood runoff and retention areas undeveloped. Another important stakeholder is agriculture. As a major land use agent, it influences the emergence of floods. Agricultural cultivation substantially contributes to flood risk reduction. Reducing surface runoff and maintaining the infiltration capacity of the soil are particularly effective, as developing land for the purpose of retention can additionally reduce floods $[43,54]$. In general, integrated flood risk management is an interdisciplinary approach including a broad range of technical and non-technical measures to reduce flood risks, in addition to giving space to rivers. This includes emergency measures, flood-adapted building, and hazard zone mapping [12].

The limitations of making room for river are not only connected to the lack of space; the implementation also needs a general shift towards an integrated flood risk management, including a wider range of stakeholders.

\section{Conclusions}

The aim of this research was to examine the development of land use in flood-prone areas in an Austrian Alpine region and the resulting potential for land use conflicts. Research was guided by two research questions:

(1) How did water bodies and settlements in flood-prone areas change between 1826-1857 and 2016 in Austrian Alpine regions? In the past, one important goal of flood prevention was making space for new settlements and intensifying agricultural production, which led to a decrease in rivers and streams by $40 \%$. Flood-prone areas (potentially affected by a 300-year flood) are nowadays more intensely used by settlements than in the mid-19th century. The amount of settlement areas located in flood-prone areas rose from $21 \%$ to $29 \%$; flood damage potential is therefore increasing.

(2) How are flood-prone areas in Alpine regions currently used (focus on settlements and agriculture)? The regional analysis of settlements located in flood-prone areas shows that in pronounced mountain regions, a higher percentage of settlements is affected by flooding. Flood-prone areas are also needed for agricultural production; $7.7 \%$ of agricultural areas in Austria are located in flood-prone areas. Looking at valuable agricultural land, $12 \%$ is affected by flooding; however, the percentage is higher in Alpine regions. In Carinthia, for example, $21 \%$ of valuable agricultural land is located in flood-prone areas.

A lack of space because of the topography, pressure on land due to settlement dynamics, and the importance of land for regional food production are key factors when it comes to the land use pressure in flood-prone areas and the limitations of a making space for rivers policy.

The increasing settlement development in flood-prone areas highlights the importance of spatial planning to preserve areas for flood runoff and retention and thus to reduce flood risk. Further research is needed on spatial planning approaches, particularly in areas with residual risk to address the 'levee-effect' and the increasing flood damage potential. Additionally, a focus in future flood risk management should be put on a more detailed differentiation of agricultural land based on economic and ecologic functions as well as on the flood-adapted cultivation of farmland.

Author Contributions: Conceptualization, L.J.; formal analysis, L.J., S.H., K.S., and K.W.; writingoriginal draft preparation, L.J., S.H., K.S., and K.W.; writing—-review and editing, L.J., S.H., K.S., W.S., and K.W.; visualization, L.J. and K.S.; project administration, W.S. All authors have read and agreed to the published version of the manuscript.

Funding: This research was conducted within the research project "Integrated Flood Risk Management in Mountain Areas: Assessing Sectoral Interdependencies, Conflicts and Options for Policy Coordination" (PoCo-FLOOD) which was funded by the Austrian Academy of Sciences (ÖAW) within the Earth System Sciences (ESS) research program. Lena Junger was supported by the Doctoral 
School "Human River Systems in the 21st Century (HR21)" of the University of Natural Resources and Life Sciences, Vienna.

Institutional Review Board Statement: Not applicable.

Informed Consent Statement: Not applicable.

Data Availability Statement: The datasets used are not readily available because the data are partly subjected to third party restriction. Selected data are available on request.

Conflicts of Interest: The authors declare no conflict of interest.

\section{Appendix A}

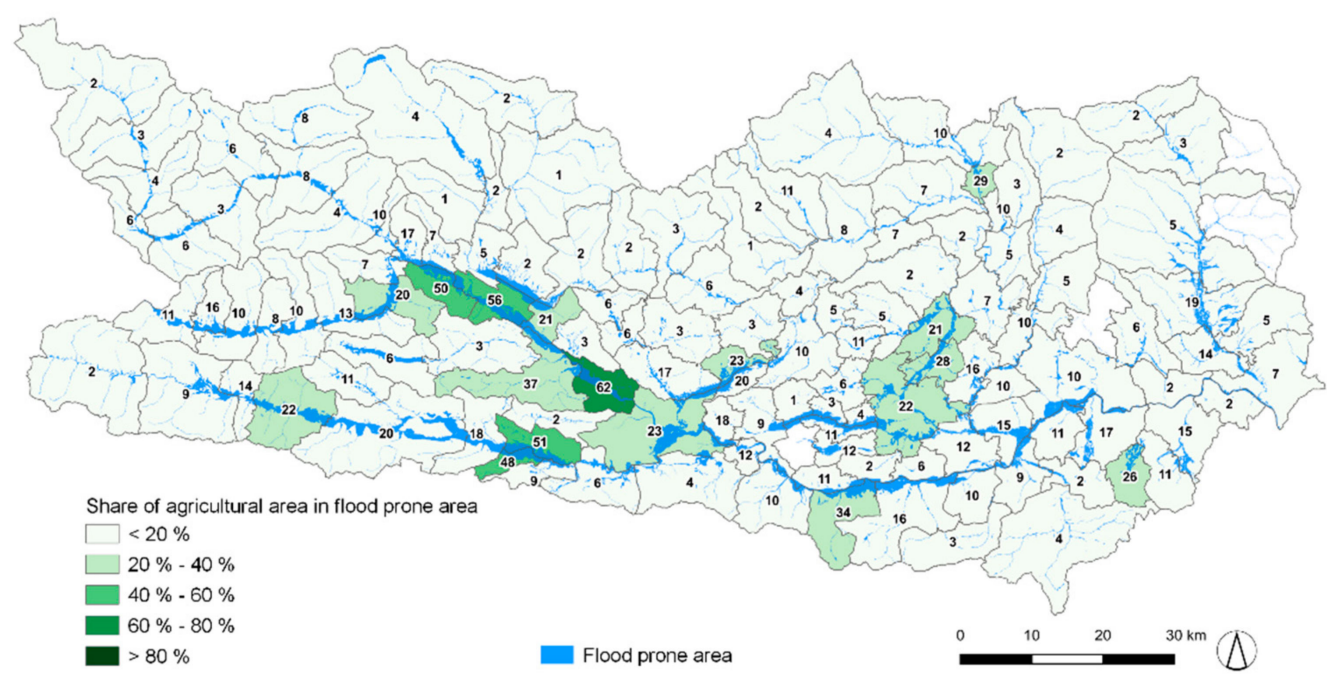

Figure A1. Share of agricultural area in Carinthia situated in flood risk zones per municipality, 2018 (source of borders: Federal Office of Metrology and Surveying (BEV)).
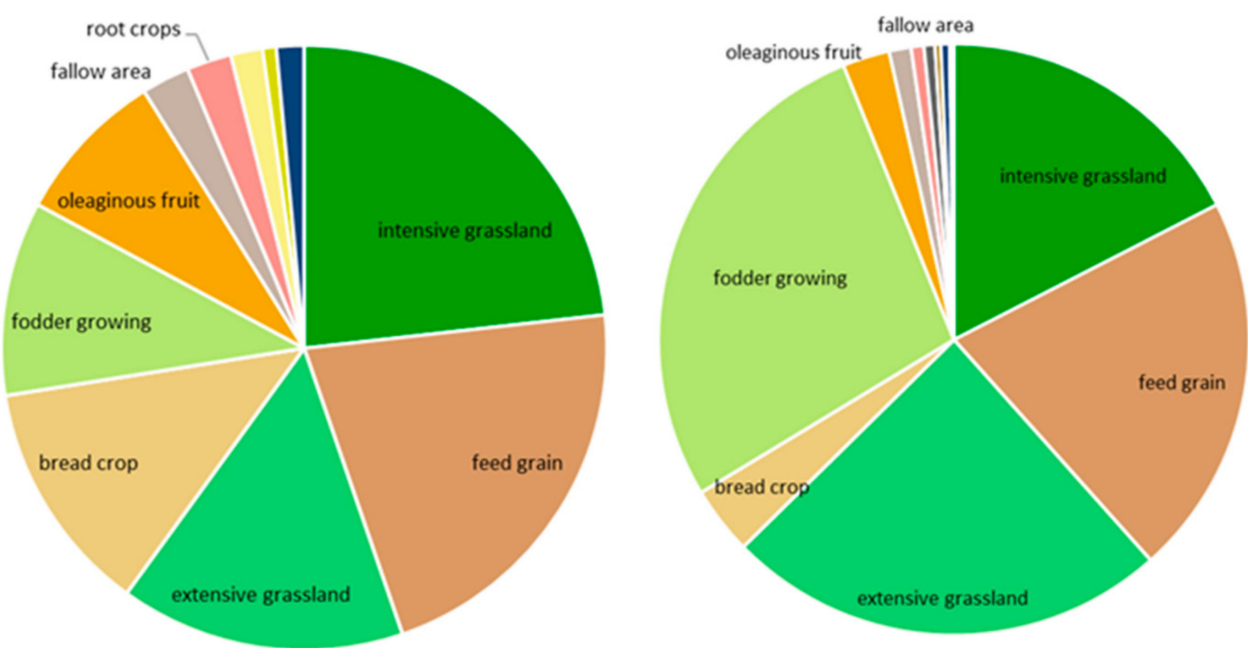

Figure A2. Agricultural land use in flood-prone areas 2018, left side: Austria, right side: Carinthia. 


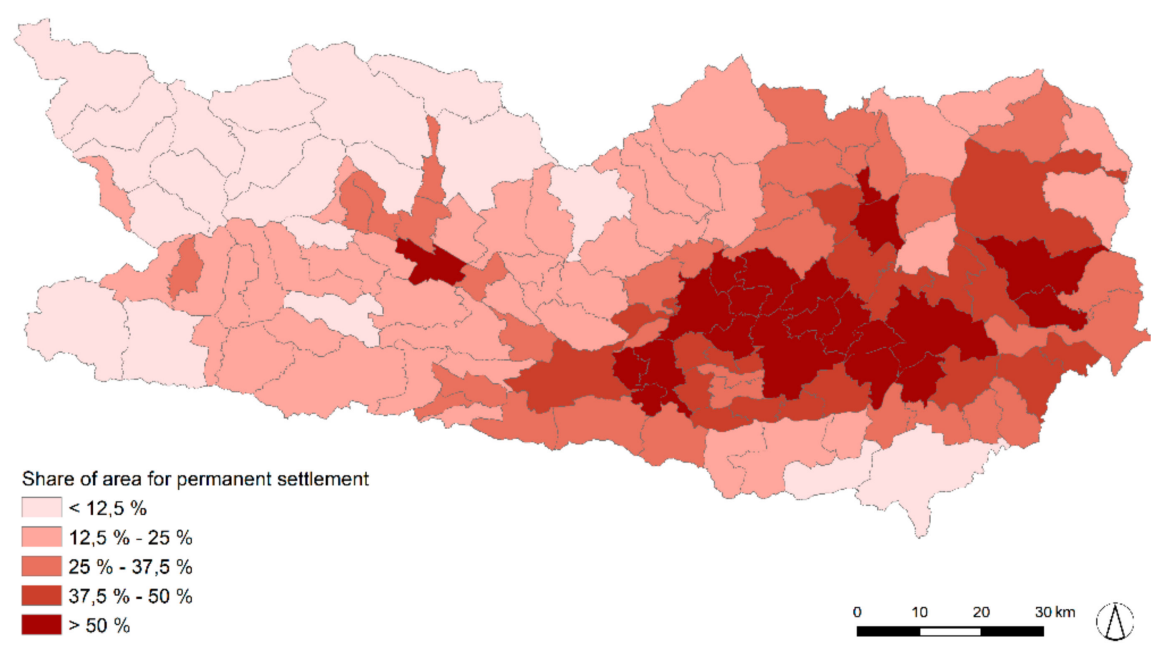

Figure A3. Share of area for permanent settlement per municipality in Carinthia (own presentation; source of borders: Federal Office of Metrology and Surveying (BEV); source of area for permanent settlement: Statistics Austria).

\section{References}

1. World Bank. Cities and Flooding; The World Bank: Washington, DC, USA, 2012; ISBN 978-0-8213-8866-2.

2. Blöschl, G.; Viglione, A.; Merz, R.; Parajka, J.; Salinas, J.L.; Schöner, W. Auswirkungen des Klimawandels auf Hochwasser und Niederwasser. Österreichische Wasser und Abfallwirtschaft 2011, 63, 21-30. [CrossRef]

3. Blöschl, G.; Blaschke, A.P.; Haslinger, K.; Hofstätter, M.; Parajka, J.; Salinas, J.; Schöner, W. Auswirkungen der Klimaänderung auf Österreichs Wasserwirtschaft—ein aktualisierter Statusbericht. Österreichische Wasser und Abfallwirtschaft 2018, 70, 462-473. [CrossRef]

4. Barredo, J.I. Normalised flood losses in Europe: 1970-2006. Nat. Hazards Earth Syst. Sci. 2009, 9, 97-104. [CrossRef]

5. Löschner, L.; Herrnegger, M.; Apperl, B.; Senoner, T.; Seher, W.; Nachtnebel, H.P. Flood risk, climate change and settlements development: A micro-scale assessment of Austria municipalities. Reg. Environ. Change 2017, 17, 311-322. [CrossRef]

6. Nachtnebel, H.P.; Apperl, B. Beurteilung des Hochwasser-Schadenspotenzials unter dynamischen Bedingungen. Österr Wasserund Abfallw 2015, 67, 120-130. [CrossRef]

7. Schanze, J. The long way towards tolerable flood risks-Initial lessons learnt from the recent Central European floods. J. Flood Risk Manag. 2013, 6, 167-168. [CrossRef]

8. Klijn, F.; Samuels, P.; van Os, A. Towards flood risk management in the EU: State of affairs with examples from various European countries. Int. J. River Basin Manag. 2008, 6, 307-321. [CrossRef]

9. Samuels, P.; Klijn, F.; Dijkman, J. An analysis of the current practice of policies on river flood risk management in different countries. Irrig. Drain. 2006, 55, S141-S150. [CrossRef]

10. Greiving, S. Räumliche Planung und Risiko; Gerling Akad. Verl.: Munich, Germany, 2002; ISBN 3-932425-50-2.

11. Sayers, P.; Yuanyuan, L.; Galloway, G.; Penning-Rowsell, E.C.; Fuxin, S.; Kang, W.; Yiwei, C.; LeQuesne, T. Flood Risk Management A Strategic Approach; Asian Development Bank: Mandaluyong City, Philippines, 2013.

12. Müller, U. Hochwasserrisikomanagement: Theorie und Praxis; Vieweg+Teubner Verlag/GWV Fachverlage GmbH Wiesbaden: Wiesbaden, Germany, 2010; ISBN 978-3-8348-1247-6.

13. Löschner, L. The Spatial Turn in Flood Risk Management: A Case Study of Austria's Changing Flood Policies. Ph.D. Thesis, University of Natural Resources and Life Sciences, Vienna, Austria, 2018.

14. Van Ruiten, L.J.; Hartmann, T. The spatial turn and the scenario approach in flood risk management-Implementing the European Floods Directive in the Netherlands. AIMS Environ. Sci. 2016, 3, 697-713. [CrossRef]

15. Warner, J.F.; van Buuren, A.; Edelenbos, J. Making Space for the River: Governance Experiences with Multifunctional River Flood Management in the US and Europe; IWA Publishing: London, UK, 2012; ISBN 9781780401133.

16. Rijke, J.; van Herk, S.; Zevenbergen, C.; Ashley, R. Room for the River: Delivering integrated river basin management in the Netherlands. Int. J. River Basin Manag. 2012, 10, 369-382. [CrossRef]

17. Busscher, T.; van den Brink, M.; Verweij, S. Strategies for integrating water management and spatial planning: Organising for spatial quality in the Dutch "Room for the River" program. J. Flood Risk Manag. 2019, 12, e12448. [CrossRef]

18. Verweij, S.; Busscher, T.; van den Brink, M. Effective policy instrument mixes for implementing integrated flood risk management: An analysis of the 'Room for the River' program. Environ. Sci. Policy 2021, 116, 204-212. [CrossRef]

19. Hartmann, T. Den Flüssen mehr Raum geben-Umsetzungsrestriktionen in Recht und Praxis. Raumforschung und Raumordnung 2011, 69, 257-268. [CrossRef]

20. Bogdan, E.A.; Beckie, M.A.; Caine, K.J. Making room for nature? Applying the Dutch Room for the River approach to flood risk management in Alberta, Canada. Int. J. River Basin Manag. 2020, 1-13. [CrossRef] 
21. Pardoe, J.; Penning-Rowsell, E.; Tunstall, S. Floodplain conflicts: Regulation and negotiation. Nat. Hazards Earth Syst. Sci. 2011, 11, 2889-2902. [CrossRef]

22. Hohensinner, S.; Egger, G.; Muhar, S.; Vaudor, L.; Piégay, H. What remains today of pre-industrial Alpine rivers? Census of historical and current channel patterns in the Alps. River Res. Applic. 2021, 37, 128-149. [CrossRef]

23. Habersack, H.; Bürgel, J.; Kanonier, A. FloodRisk II: Vertiefung und Vernetzung Zukunftsweisender Umsetzungsstrategien Zum Integrierten Hochwassermanagement; Synthesebericht: Vienna, Austria, 2009.

24. Rohde, S.; Hostmann, M.; Peter, A.; Ewald, K.C. Room for rivers: An integrative search strategy for floodplain restoration. Landsc. Urban Plan. 2006, 78, 50-70. [CrossRef]

25. Trautwein, C.; Schinegger, R.; Schmutz, S. Cumulative effects of land use on fish metrics in different types of running waters in Austria. Aquat. Sci. 2012, 74, 329-341. [CrossRef]

26. Mantyka-Pringle, C.S.; Martin, T.G.; Moffatt, D.B.; Linke, S.; Rhodes, J.R. Understanding and predicting the combined effects of climate change and land-use change on freshwater macroinvertebrates and fish. J. Appl. Ecol. 2014, 51, 572-581. [CrossRef]

27. Ceola, S.; Laio, F.; Montanari, A. Satellite nighttime lights reveal increasing human exposure to floods worldwide. Geophys. Res. Lett. 2014, 41, 7184-7190. [CrossRef]

28. Cammerer, H.; Thieken, A.H.; Verburg, P.H. Spatio-temporal dynamics in the flood exposure due to land use changes in the Alpine Lech Valley in Tyrol (Austria). Nat. Hazards 2013, 68, 1243-1270. [CrossRef]

29. Fuchs, S.; Margreth, K.; Zischg, A. A spatiotemporal multi-hazard exposure assessment based on property data. Nat. Hazards Earth Syst. Sci. 2015, 15, 2127-2142. [CrossRef]

30. Grüneis, H.; Schroll, K.; Wagner, K. The Role of Agriculture in Flood Risk Management in Austria-Conflicts and Challenges JESE-B 2021, 10, 112-127. [CrossRef]

31. Agrawala, S. Climate Change in the European Alps: Adapting Winter Tourism and Natural Hazards Management; OECD Organisation for Economic Co-Operation and Development: Paris, France, 2007; ISBN 92-64-03168-5.

32. Alpine Convention. Demographic Changes in the Alps: Report on the State of the Alps. Alpine Convention Alpine Signals-Special Edition 5, Bozen. 2015. Available online: https://www.alpconv.org/fileadmin/user_upload/Publications/RSA/RSA5_EN.pdf (accessed on 7 February 2022).

33. Umweltbundesamt. Flächeninanspruchnahme. Available online: https://www.umweltbundesamt.at/umweltthemen/boden/ flaecheninanspruchnahme (accessed on 7 February 2022).

34. Löschner, L.; Eder, M.; Herrnegger, M.; Hogl, K.; Nordbeck, R.; Scherhaufer, P.; Schober, B.; Seher, W.; Wesemann, J.; Zahnt, N.; et al. RegioFEM-Informing future-oriented flood risk management at the regional scale (Part I). J. Flood Risk Manage. 2021, 15, e12754. [CrossRef]

35. Hohensinner, S.; Atzler, U.; Berger, M.; Bozzetta, T.; Höberth, C.; Kofler, M.; Rapottnig, L.; Sterle, Y.; Haidvogl, G. Land Use and Cover Change in the Industrial Era: A Spatial Analysis of Alpine River Catchments and Fluvial Corridors. Front. Environ. Sci. 2021, 9, 647247. [CrossRef]

36. GeoVille Information Systems. Cadasterenv-Final Report (TD-9): Public Version I 1.0. Available online: https://www. landinformationsystem.at/\#/lisa/overview (accessed on 23 December 2021).

37. BMLFUW; BAB. INVEKOS-Datenpool 2017 des BMLFUW. Available online: https://info.bmlrt.gv.at/themen/landwirtschaft/ eu-agrarpolitik-foerderungen/direktzahlungen/Invekos.html (accessed on 23 January 2022).

38. Buckel, J.; Otto, J.-C. The Austrian Glacier Inventory GI 4 (2015) in ArcGis (shapefile) Format; PANGAEA: Bremen, Germany, 2018.

39. Ramm, F.; OpenStreetMap Data in Layered GIS Format. Technical Report. Available online: https://download.geofabrik.de/ europe/austria.html (accessed on 23 December 2021).

40. Muhar, S.; Grüner, B.; Böck, K.; Scheikl, S.; Becsi, R. SPARE Synthesis Report: "Balancing River Protection Needs, Ecosystem Functions and Human Uses"; University of Natural Resources and Life ServicesL: Vienna, Austria, 2018.

41. Haslmayr, H.-P.; Baumgarten, A.; Schwarz, M.; Huber, S.; Prokop, G.; Sedy, K.; Krammer, C.; Murer, E.; Pock, H.; Rodlauer, C.; et al. BEAT-Bodenbedarf für die Ernährungssicherung in Österreich: Endbericht zum Forschungsprojekt Nr. 100975; Vienna, Austria. 2018. Available online: https://dafne.at/content/report_release/aa85879d-af0f-4273-a1e2-b7f1d7178d41_0.pdf (accessed on 23 December 2021)

42. BAB. Standard-Output-Koeffizienten der Pflanzlichen Erzeugung nach Schlagnutzungsarten; BAB: Vienna, Austria, 2021.

43. BMLRT. Grüner Bericht 2021 Die Situation der österreichischen Land- und Forstwirtschaft: Gemäß §9 des Landwirtschaftgesetzes; BMLRT: Vienna, Austria, 2021. Available online: https://gruenerbericht.at/cm4/jdownload/send/2-gr-bericht-terreich/2393-gb2021 (accessed on 23 December 2021).

44. Papilloud, T.; Röthlisberger, V.; Loreti, S.; Keiler, M. Flood exposure analysis of road infrastructure-Comparison of different methods at national level. Int. J. Disaster Risk Reduct. 2020, 47, 101548. [CrossRef]

45. Lebiedzinski, K.; Fürst, J.; Schulz, K.; Herrnegger, M. Possible impacts of a hydropower reservoir on the flood hazard of an Alpine valley. In Proceedings of the EGU General Assembly 2020, Vienna, Austria, 3-8 May 2020.

46. Jansson, P.; Hock, R.; Schneider, T. The concept of glacier storage: A review. J. Hydrol. 2003, 282, 116-129. [CrossRef]

47. Früh-Müller, A.; Wegmann, M.; Koellner, T. Flood exposure and settlement expansion since pre-industrial times in 1850 until 2011 in north Bavaria, Germany. Reg. Environ. Change 2015, 15, 183-193. [CrossRef]

48. Serrano-Notivoli, R.; Mora, D.; Ollero, A.; Sánchez-Fabre, M.; Sanz, P.; Saz, M.Á. Ocupación de la llanura aluvial e inundaciones en el Pirineo Central. CIG 2017, 43, 309. [CrossRef] 
49. Poppe, M.; Muhar, S.; Gregory, E.; Stefan, S. Status quo der österreichischen Flusslandschaften: Erfassung und Bilanzierung der Eingriffe und Nutzungen. Österreichische Wasser- und Abfallwirtschaft 2003, 7-8, 122-128.

50. Haidvogl, G.; Eberstaller, J.; Eberstaller-Fleischanderl, D.; Fraiß, B.; Gabriel, H.; Hohensinner, S. Historische Landnutzung und Siedlungsentwicklung in Flussauen und Hochwasserschutz: Das Beispiel der Traisen und St. Pöltens 1870-2000. Österr Wasserund Abfallw 2018, 70, 305-315. [CrossRef]

51. Merz, B. Hochwasserrisiken: Grenzen und Möglichkeiten der Risikoabschätzung Mit 33 Tabellen; Schweizerbart: Stuttgart, Germany, 2006; ISBN 3-510-65220-7.

52. Burby, R.J. Hurricane Katrina and the Paradoxes of Government Disaster Policy: Bringing About Wise Governmental Decisions for Hazardous Areas. ANNALS Am. Acad. Political Soc. Sci. 2006, 604, 171-191. [CrossRef]

53. Di Baldassarre, G.; Kreibich, H.; Vorogushyn, S.; Aerts, J.; Arnbjerg-Nielsen, K.; Barendrecht, M.; Bates, P.; Borga, M.; Botzen, W.; Bubeck, P.; et al. Hess Opinions: An interdisciplinary research agenda to explore the unintended consequences of structural flood protection. Hydrol. Earth Syst. Sci. 2018, 22, 5629-5637. [CrossRef]

54. Zischg, A.; Costa, R.; Flury, C.; Schild, A. Einfluß der landwirtschaftlichen Bewirtschaftung auf alpine Naturgefahren eine zusammenfassende Betrachtung. In Proceedings of the 12th Congress INTERPRAEVENT, Grenoble, France, $23-26$ April 2012. 